ance from one kind of bacterium to another has only since been recognized. Moreover, the emergence and prevalence of drug-resistant strains of bacteria in animal husbandry has only more recently become substantial. The most obvious danger is that the multiplication of resistant strains of pathogenic bacteria will take a serious toll of the animals now being kept in increasing numbers in conditions of intensive farming. More distantly, however, there is the grisly prospect that the prevalence of resistant bacteria among animals will throw up resistant human infections. In circumstances like these, it is more than a little fatuous for committees to say, as the Scientific Advisory Panel of the Ministry of Agriculture reported to its minister earlier this year (see Hansard, January 31, column 239), that "antibiotic resistance has always existed and this is one of the reasons why a wide range of antibiotics has been needed to control infections". The truth is that there is a real problem to be tackled even though it would be wrong at this stage to suggest that British veterinary practice has already passed the danger point. It will be a great surprise if Professor Swann's committee can answer all the questions that will be asked of it in the next few months.

What then is to be done? As things are, the use of three antibiotics as additions to pig and poultry food is permitted and the chances are that poultry farming has already become dependent on the use of these materials. But nobody has a very clear picture of the scale on which these materials are being used or of the economic benefit which they confer. Do farm animals grow fatter quicker if they are kept in dark houses and fed antibiotics than if they are allowed to roam more freely without medication? Quite apart from the risks to human health, these are difficult problems in animal husbandry which deserve the most careful attention. There are also important questions to be decided about the possibility of helping to keep the risk of accumulative resistance at bay by the careful management of livestock. The committee, under Professor Swann, seems to be anxious to take up all kinds of interesting problems like these as well as to give proper attention to the needs of human health and safety. The fear that the committee will turn out to be a lobby for the veterinarians, quite proper, seems to be unfounded. Whether the committee will fall a victim to that kind of conservatism the chief symptom of which is complacency remains to be determined.

Even at this stage, however, one general principle should be clear. Among the recommendations of the new committee there is certain to be an exhortation that "the situation should continue to be watched". The Swann committee may even go farther than its several predecessors in suggesting what kind of machinery there should be to carry out this task. It is anomalous that the British Government which, in fields like technology, is prone to shoulder more responsibility for research than it can comfortably manage, is in fields like this inclined to delegate responsibility to other organizations. In practice, for example, the chief agency for investigating experi- mentally the safety of food additives is the British Industrial Biological Research Association which is, in theory at least, a publicly supported consortium of industrial companies. In the same somewhat lackadaisical way, the Government tends to rely for advice on committees which are usually characterized by their combination of conflicting interests-a device which is as productive of compromise as of consensus. But in the long run it is hard to see how the British Government can avoid taking yet another leaf out of the American book and resolving to establish an autonomous agency, equivalent to the Food and Drug Administration, which would be free to make enemies if it pleases in a field in which some enemies are bound to be almost irreconcilable. This is the sense in which the working of the Swann committee will deserve, and will no doubt get, the closest attention.

\section{Minister in Trouble}

Mr EDward Short, the new Secretary of State for Education and Science, has been popular with teachers in his first few weeks of office but seems to be running into trouble with the universities and even with seientists. For one thing, the Council for Scientific Policy has written to $\mathrm{Mr}$ Short to complain that it was not kept properly informed about the decision not to participate in the $300 \mathrm{GeV}$ accelerator project at CERN. More openly, Professor Michael Swann, principal of the University of Edinburgh, has joined with the local head of the Association of University Teachers and the president of the Students' Council to protest at the things which $\mathrm{Mr}$ Short has been saying about the universities. What seems to have rattled the academics is $\mathrm{Mr}$ Short's request that "the authoritarian regimes which still persist in too many of our universities" should be liberalized. Professor Swann and his colleagues argue that this "sweeping condemnation ... can hardly fail to be used as an excuse by extremists for causing trouble" and, at the same time, strengthen "anti-student feeling" outside the universities. They go on to claim that British universities, and particularly Scottish universities, are as liberal as anybody could expect and they invite Mr Short to eat his words.

There is no doubt that this direct challenge to the minister by a distinguished academic breaks new ground in the relations between British universities and the government. If he is wise, Mr Short will read this as an ominous sign. Vice-chancellors at other universities will at the same time marvel at the cleverness with which Professor Swann has ensured that he will be supported by the representatives of his students and his staff if there is what people call trouble next academic year.

\section{Too Little, Too Thin}

Predictably the report of the Working Group on Molecular Biology (HMSO 2s. 6d.) of the Council for Scientific Policy makes gloomy reading. The working group, under the chairmanship of Dr J. C. Kendrew, says that there is too little research on molecular biology in Britain and that most of what there is tends to be so widely scattered that its value is dubious. According 